University of Nebraska - Lincoln

DigitalCommons@University of Nebraska - Lincoln

Publications from USDA-ARS / UNL Faculty

U.S. Department of Agriculture: Agricultural

Research Service, Lincoln, Nebraska

2017

\title{
Rooting and vegetative growth of hardwood cuttings of 12 pomegranate (Punica granatum L.) cultivars
}

John M. Chater

University of California, Riverside, jchat004@ucr.edu

Donald J. Merhaut

University of California, Riverside, donald.merhaut@ucr.edu

John E. Preece

University of California, Davis, John.Preece@ars.usda.gov

Eugene K. Blythe

Mississippi State University, ekb59@msstate.edu

Follow this and additional works at: https://digitalcommons.unl.edu/usdaarsfacpub

Chater, John M.; Merhaut, Donald J.; Preece, John E.; and Blythe, Eugene K., "Rooting and vegetative growth of hardwood cuttings of 12 pomegranate (Punica granatum L.) cultivars" (2017). Publications from USDA-ARS / UNL Faculty. 1828.

https://digitalcommons.unl.edu/usdaarsfacpub/1828

This Article is brought to you for free and open access by the U.S. Department of Agriculture: Agricultural Research Service, Lincoln, Nebraska at DigitalCommons@University of Nebraska - Lincoln. It has been accepted for inclusion in Publications from USDA-ARS / UNL Faculty by an authorized administrator of DigitalCommons@University of Nebraska - Lincoln. 


\title{
Rooting and vegetative growth of hardwood cuttings of 12 pomegranate (Punica granatum L.) cultivars
}

\author{
John M. Chater ${ }^{\mathrm{a}, *}$, Donald J. Merhaut ${ }^{\mathrm{a}}$, John E. Preece ${ }^{\mathrm{b}}$, Eugene K. Blythe \\ a Department of Botany and Plant Sciences, 900 University Avenue, University of California, Riverside, CA 92521, USA \\ b National Clonal Germplasm Repository, USDA-ARS, One Shields Avenue, University of California, Davis, CA 95616-8607, USA \\ c Coastal Research and Extension Center, Mississippi State University, 810 Highway 26 West Poplarville, MS 39470, USA
}

\section{A R T I C L E I N F O}

\section{Keywords:}

Auxin

Indole-3-butyric acid

Vegetative propagation

Rooting

'Wonderful'

\begin{abstract}
A B S T R A C T
Commercial pomegranate production area has increased substantially in the western hemisphere due to increased consumer interest in the fruit. Low nursery inventory has caused many growers to propagate vegetatively their own trees and the availability of only a few cultivars is believed to have played a role in a lack of diversity in the developing market. 'Wonderful,' the industry standard for pomegranate in several countries, has been propagated in the United States for over 100 years, yet there is limited scientific information regarding how to most effectively propagate 'Wonderful' and other important cultivars. This research included two experiments. Experiment 1 evaluated rooting percentages and vegetative growth attributes of hardwood cuttings of twelve cultivars ('Ambrosia,' 'Desertnyi,' 'Eversweet,' 'Golden Globe,' 'Green Globe,' 'Haku Botan,' 'Ki Zakuro,' 'Loffani,' 'Nochi Shibori,' 'Parfianka,' 'Phoenicia,' and 'Wonderful') utilizing a basal dip in a gel formulation of 3 $\mathrm{g} \cdot \mathrm{L}^{-1}$ indole-3-butyric acid (IBA). Experiment 2 evaluated auxin treatments which consisted of basal dip in water only (control) or a gel formulation of IBA $\left(1.5 \mathrm{~g} \mathrm{~L}^{-1}\right.$ or $\left.3 \mathrm{~g} \mathrm{~L}^{-1}\right)$ for hardwood cuttings of 'Wonderful' and two cultivars that rooted poorly in Experiment 1: 'Ambrosia' and 'Green Globe.' Measured response attributes included rooting success percentages, dry root mass, leaf area, plant height, number of shoots, apical shoot growth, total shoot length, branching, stem diameter, and relative chlorophyll content (SPAD value). 'Wonderful' and nine other cultivars rooted over $84 \%$ of the time using cuttings treated with $3 \mathrm{~g} \mathrm{~L}^{-1}$ IBA. $^{-}$ Differences in plant height and branching could be detected early in production. The effect of IBA concentration on rooting percentage and growth attributes varied among cultivars. Cuttings of 'Ambrosia' rooted best with $3 \mathrm{~g} \mathrm{~L}^{-1}$ IBA versus 0 and $1.5 \mathrm{~g} \mathrm{~L}^{-1}$ IBA, whereas rooting of cuttings of 'Green Globe' was similar among IBA rates. Plants of 'Wonderful' had significantly greater leaf area compared to those of 'Ambrosia' and 'Green Globe.' Stem diameter had no effect on rooting on any cultivar in either experiment. There were significant differences among cultivars in terms of chlorophyll content, with 'Haku Botan' and 'Loffani' having greener leaves than 'Eversweet,' 'Ambrosia,' and 'Desertnyi.'
\end{abstract}

\section{Introduction}

Pomegranate is a woody, fruit-bearing tree crop belonging to the family Lythraceae (Graham et al., 2005). Pomegranate has been cultivated for thousands of years and is considered to be one of the first fruit species to be domesticated (Still, 2006). Interest and production of pomegranate has increased due to discovery and quantification of various classes of polyphenolic compounds which have high antioxidant activity (Gil et al., 2000) and are believed to have health benefits for humans (Lansky and Newman, 2007). In California, land use for pomegranate production increased from about 1000 ha in the 1990 s to over 11,000 ha in 2009 . Due to limited nursery stock, many growers have clonally propagated their own trees (Day and Wilkins, 2009), which is believed to have led to a lack of diversity in the market in the United States, with the vast majority of hectares planted in California with 'Wonderful,' a single genotype.

Vegetative propagation of pomegranate can be accomplished through air layering, softwood cuttings, dormant hardwood cuttings, tissue culture, and grafting. However, commercial propagation is typically performed via hardwood stem cuttings (Karimi, 2011; Polat and Caliskan, 2006) because it shortens the duration of plant juvenility, and growers and nurseries typically do not have access to tissue culture (micropropagation) technologies. There are known to be differences in propagation success using hardwood cuttings among pomegranate

\footnotetext{
* Corresponding author.

E-mail addresses: jchat004@ucr.edu (J.M. Chater), donald.merhaut@ucr.edu (D.J. Merhaut), John.Preece@ars.usda.gov (J.E. Preece), ekb59@msstate.edu (E.K. Blythe).
} 
cultivars in national collections (Kennedy, 2010). There are also differences in rooting percentages based on interactions among cultivar, concentration of root-promoting compound, and cutting type (Owais, 2010). The most common root-promoting compound in the nursery industry is indole-3-butyric acid (IBA) (Hartmann et al., 2001). Singh et al. (2011) reported highest rooting success (90\%) using $2 \mathrm{~g} \mathrm{~L}^{-1}$ IBA when treating 20-cm-long hardwood cuttings. Owais (2010) reported similar rooting percentage with $9 \mathrm{~g} \mathrm{~L}^{-1}$ IBA (92.6\%) compared to 0 or $3 \mathrm{~g} \mathrm{~L}^{-1}$ IBA (43.9\% and $57.9 \%$, respectively). However, Polat and Caliskan (2006) reported a maximum rooting percentage of $86.7 \%$ using $1 \mathrm{~g} \mathrm{~L}^{-1}$ IBA on 20-25-cm-long hardwood cuttings. Although there have been various studies on pomegranate propagation, no known experiments have focused on rooting from dormant hardwood cuttings of Punica cultivars from the U.S. Department of Agriculture National Clonal Germplasm Repository for Tree Fruit and Nut Crops and Grapes, Davis, CA (USDA NCGR), which contains approximately 300 pomegranate cultivars. For these experiments, all plant material was sourced from mature trees at the same national germplasm field site, serving as a common environment so that all attributes could be compared across genotype. Although many of these cultivars have been bred for commercial applications, limited phenotypic horticultural information is available for this germplasm material, including propagation methods.

The objectives of this research were: 1) to evaluate the effect of cultivar on rooting success and vegetative growth; and 2) to evaluate the effects of IBA concentrations on the rooting success and vegetative growth attributes of difficult-to-root pomegranate cultivars.

\section{Materials and methods}

\subsection{Plant material and experimental design}

The pomegranate cultivars used in the following studies were: 'Ambrosia,' 'Desertnyi,' 'Eversweet,' 'Golden Globe,' 'Green Globe,' 'Haku Botan,' 'Ki Zakuro,' 'Loffani,' 'Nochi Shibori,' 'Parfianka,' 'Phoenicia,' and 'Wonderful.' All cultivars used in this experiment are located at the USDA NCGR, but the cultivars conserved in this national germplasm collection were originally sourced from different countries. 'Ambrosia,' 'Eversweet,' 'Golden Globe,' 'Green Globe,' 'Loffani,' 'Phoenicia,' and 'Wonderful' originated in the United States. 'Desertnyi' and 'Parfianka' originated in Turkmenistan. 'Haku Botan,' 'Ki Zakuro,' and 'Nochi Shibori' originated in Japan, with 'Haku Botan' being a fruiting edible ornamental cultivar with no red pigment and 'Ki Zakuro,' and 'Nochi Shibori' being sterile, producing no fruit. All three Japanese cultivars have "double flowers" with up to hundreds of petals per flower and an upright growth habit. 'Eversweet' and 'Desertnyi' have dwarf-like growth characteristics in the field, with trees typically being approximately $20-30 \%$ shorter or less vigorous than 'Wonderful' as measured in the University of California, Riverside pomegranate cultivar trials. 'Parfianka' has a canopy with a bushy growth habit and is thornier than many other cultivars. Differences in bark characteristics were not observable. The first experiment (Experiment 1) included all abovementioned cultivars, and the second experiment (Experiment 2) consisted of the following cultivars: 'Ambrosia,' 'Green Globe' and 'Wonderful.' Cuttings were sourced from the USDA NCGR in Winters, CA.

Dormant stems were collected from basal suckers in February of 2013 and 2014 for Experiment 1 and Experiment 2, respectively, placed in a plastic bag with a wet paper towel to keep them moist, driven to Davis, CA, boxed, and shipped via private delivery service from Davis, CA to Riverside, CA for second-day delivery. Upon arrival, the plant material was unwrapped and rewrapped with new moistened paper towels and stored at $5-6{ }^{\circ} \mathrm{C}$ in the dark for approximately 2 months before preparation of cuttings.

All cuttings were sourced from one year old growth and mean diameter ranged from $3.8-5.8 \mathrm{~mm}$ among cultivars. Cuttings were prepared $10.5 \pm 1.0 \mathrm{~cm}$ long with a minimum of two nodes (one above ground, one below ground), treated with IBA or control, and inserted $3-5 \mathrm{~cm}$ deep in $2.5 \mathrm{~cm} \times 2.5 \mathrm{~cm}$ plastic pots containing \#4 Sunshine potting mix (Sun Gro Horticulture, Agawam, MA, USA): 1 perlite (by volume). Treatments were separated by block in plastic flats. Both experiments were conducted in a greenhouse at the University of California, Riverside $\left(33^{\circ} 58^{\prime} 20.21^{\prime \prime} \mathrm{N}, 117^{\circ} 19^{\prime} 27.43^{\prime \prime} \mathrm{W}\right)$ with mean temperatures of $24.1{ }^{\circ} \mathrm{C}$ and $26.3^{\circ} \mathrm{C}$ for Experiment 1 and Experiment 2, respectively, and natural photoperiod. Cuttings were hand-watered with deionized water every day for 5 weeks, then watered as needed (every other day on average). Starting at week 10, water source was switched to municipal water and all plants were treated with Plantex ${ }^{\mathrm{TM}}$ (Master Plant-Prod Inc., Brampton, ON, Canada) water soluble fertilizer, which contained $20-8.7-16.7 \% \mathrm{~N}-\mathrm{P}-\mathrm{K}$ plus micronutrients, at a rate of 200 ppm nitrogen.

\subsubsection{Design of Experiment 1: cultivar comparisons}

This experiment was conducted to determine if differences in rooting percentages and vegetative growth attributes exist among cultivars. The experiment ran from 11 March until 09 August 2013 and consisted of a randomized complete block design (RCBD) with eight blocks. Each block included four hardwood stem cuttings of each cultivar, totaling 32 cuttings per cultivar. All cuttings were treated for $5 \mathrm{~s}$ to a depth of $2-4 \mathrm{~cm}$ in a gelatinous formulation of $3 \mathrm{~g} \mathrm{~L}^{-1}$ IBA (Clonex Rooting Compound; Lansing, MI, USA) before insertion in the rooting medium.

\subsubsection{Design of Experiment 2: IBA comparisons}

This experiment was conducted to test effects of IBA concentration on rooting percentages and vegetative growth attributes of 'Wonderful' (which had nearly $100 \%$ rooting success in Experiment 1), 'Green Globe,' and 'Ambrosia' (which both rooted less successfully than all other cultivars in Experiment 1). Experiment 2 ran from 02 April until 28 December 2014 and used a RCBD with four blocks, each with four cuttings per cultivar-IBA combination, totaling 48 cuttings for each of the three cultivars. IBA was applied in the same manner as in Experiment 1, except that cuttings were dipped in either DI water (control) or IBA (Clonex) at $1.5 \mathrm{~g} \mathrm{~L}^{-1}$ or $3 \mathrm{~g} \mathrm{~L}^{-1}$ IBA (Clonex) before insertion in potting mix.

\subsection{Measured attributes}

Attributes measured in both experiments included initial stem diameter, rooting percentage, plant height, number of shoots, and total shoot growth (length). Rooting percentages were based on cuttings that successfully rooted and developed into plants. Plant height, number of shoots, and total shoot growth were assessed at the end of each experiment: day 154 (09 August 2013) for Experiment 1 and day 270 (28 December 2014) for Experiment 2. Experiment 2 was conducted over a longer time to allow for assessment of growth after a full growing season. Plant height was measured using the top of the potting container as the reference point to determine if there were differences among cultivar phenotypes for upright versus drooping growth habit. 'Wonderful' pomegranate grows in willowy tree form, but there are cultivars with upright growth habit, so this growth habit trait was assessed by measuring both apical shoot growth and plant height. Number of primary shoots represented a count of shoots growing from aboveground, lateral buds on the cutting. Total shoot growth was the sum of lengths of all primary and lateral shoots.

Attributes measured at the end of Experiment 1 were apical shoot growth (length of apically dominant shoot), branching (total number of primary and lateral shoots), and relative chlorophyll content (SPAD value). SPAD values (mean of three leaves per plant) were used to assess plant health by quantifying leaf relative chlorophyll content using a SPAD-502 chlorophyll meter (Minolta, Japan).

Attributes measured at the end of Experiment 2 were total leaf area and root dry mass. Total leaf area was measured with a LI-COR Model 
3100 Area Meter (Lincoln, Nebraska, USA). Dry root mass (g) was determined by removing the roots from the plant, drying the roots in a forced air oven to constant weight, and weighing the dried roots.

\subsection{Statistical analyses}

Data were analyzed using linear mixed models and generalized linear mixed models with the GLIMMIX procedure of SAS (version 9.4; SAS Institute Inc., Cary, NC). The normal or log-normal distribution and identity link function were used for continuous response data, the Poisson distribution and log link function for count data, and the binary distribution and logit link function for binary data. Inverse link functions were used to transform predicted means back to the original units of measure for presentation. $P$-values for multiple mean comparisons were adjusted with the Holm-Tukey method. Potential relationships between vegetative and rooting attributes were analyzed using linear regression $(\alpha=0.05)$.

\section{Results}

\section{Experiment 1. Rooting Percentages}

Cuttings of most cultivars successfully rooted over $90 \%$. Cuttings of 'Green Globe' and 'Ambrosia' exhibited the lowest rooting percentages (21.9\% and $62.5 \%$, respectively) (Table 1$)$. Although there were significant differences among cultivars in initial stem diameter of the cuttings, stem diameter did not have a significant effect on rooting or any other attribute (based on assessment with regression analysis; results not presented).

\subsection{Vegetative growth}

Plants of 'Golden Globe' and 'Phoenicia' grew taller than those of 'Eversweet' and 'Haku Botan' (27.3, 27.2, 20.0, and $19.4 \mathrm{~cm}$, respectively) (Table 1). Apical shoots were longer with 'Golden Globe,' 'Phoenicia,' and 'Wonderful' (27.0, 26.3, and $25.8 \mathrm{~cm}$, respectively) than with 'Ki Zakuro,' and 'Haku Botan' (19.7 and $18.2 \mathrm{~cm}$, respectively). Total shoot growth, a measure of vigor, was greatest with 'Wonderful' (41.6 cm) and least with 'Haku Botan' (23.8 cm) (Table 1).

'Parfianka' had the most branching ( 3.7 branches per cutting) (Table 1). A better branching habit, and thus more foliar coverage, has the potential to influence yield and reduce sunscald of fruit. With one exception, the number of primary shoots per plant was similar among cultivars (Table 1), and new shoots developed from most aboveground buds.

Relative chlorophyll content of plants across all cultivars had a mean SPAD value of 34.0 (Table 1). 'Wonderful' plants had a mean
Table 2

Simple effects means for rooting and vegetative growth responses of hardwood cuttings of three pomegranate cultivars that were not treated (control) or treated with a basal dip in a gel formulation of 1.5 or $3 \mathrm{~g} \mathrm{~L}^{-1}$ indole-3-butyric acid (IBA), then rooted and grown in a greenhouse for nine months (Experiment 2). Means and groupings are separated within cultivar.

\begin{tabular}{llllll}
\hline Cultivar & IBA & Rooting (\%) & $\begin{array}{l}\text { Dry root } \\
\text { mass }(\mathrm{g})^{\mathrm{a}}\end{array}$ & $\begin{array}{l}\text { Plant height } \\
(\mathrm{cm})^{\mathrm{a}}\end{array}$ & $\begin{array}{l}\text { Total shoot } \\
\text { length }(\mathrm{cm})^{\mathrm{a}}\end{array}$ \\
\hline Ambrosia & Control & $13 \mathrm{~b}^{\mathrm{b}}$ & 0.25 & $8.2 \mathrm{a}$ & $6.6 \mathrm{a}$ \\
& $1.5 \mathrm{~g} \mathrm{~L}^{-1}$ & $19 \mathrm{~b}$ & 0.08 & $2.6 \mathrm{~b}$ & $1.1 \mathrm{~b}$ \\
& $3 \mathrm{~g} \mathrm{~L}^{-1}$ & $56 \mathrm{a}$ & 0.21 & $6.2 \mathrm{a}$ & $7.4 \mathrm{a}$ \\
& & $<0.0001$ & $\mathrm{NS}$ & $<0.0001$ & $<0.0001$ \\
Green Globe & Control & 13 & $0.47 \mathrm{a}$ & 3.7 & 1.9 \\
& $1.5 \mathrm{~g} \mathrm{~L}^{-1}$ & 31 & $0.03 \mathrm{~b}$ & 3.7 & 0.6 \\
& $3 \mathrm{~g} \mathrm{~L}^{-1}$ & 31 & $0.15 \mathrm{a}$ & 4.7 & 0.8 \\
& & $\mathrm{NS}$ & 0.0255 & $\mathrm{NS}$ & $\mathrm{NS}$ \\
Wonderful & $\mathrm{Control}^{-1}$ & 100 & 0.18 & 13.1 & 24.3 \\
& $1.5 \mathrm{~g} \mathrm{~L}^{-1}$ & 94 & 0.21 & 10.2 & 18.8 \\
& $3 \mathrm{~g} \mathrm{~L}^{-1}$ & 100 & 0.21 & 13.0 & 25.7 \\
$P$-values & & $\mathrm{NS}$ & $\mathrm{NS}$ & $\mathrm{NS}$ & $\mathrm{NS}$ \\
\hline
\end{tabular}

\footnotetext{
${ }^{\text {a }}$ Rooted cuttings only.

b Means within a column followed by a common letter are not significantly different at $P<0.05$ using the Holm-Tukey method.
}

SPAD value of 33.7. There were significant differences among cultivars in terms of chlorophyll content, with 'Haku Botan' and 'Loffani' having greener leaves than 'Eversweet,' 'Ambrosia,' and 'Desertnyi.'

Experiment 2. Stem diameter, rooting percentage, and root dry mass

Stem diameters of cuttings at the initiation of the experiment were significantly different among cultivars, with 'Wonderful' having greater stem diameter than 'Green Globe' and 'Ambrosia' (data not shown), but these differences had no significant effect on rooting. Cuttings of 'Wonderful' rooted significantly better than those of 'Ambrosia' or 'Green Globe.' Cuttings of 'Ambrosia' had higher rooting percentage with $3 \mathrm{~g} \mathrm{~L}^{-1}$ IBA versus 0 and $1.5 \mathrm{~g} \mathrm{~L}^{-1} \mathrm{IBA}$, whereas rooting of cuttings of 'Green Globe' was similar among IBA rates (Table 2). Cuttings of 'Green Globe' with no IBA application produced greater root dry mass than other cultivar-IBA combinations.

\subsection{Vegetative growth}

The effect of IBA on plant height varied for cuttings of 'Ambrosia', but not for 'Green Globe' or 'Wonderful' (Table 2). Plants of 'Wonderful' were typically taller than both plants of 'Green Globe' and 'Ambrosia' (except for plants of 'Ambrosia' not treated with IBA).

Plants of 'Wonderful' had significantly greater leaf area compared to those of 'Ambrosia' and 'Green Globe' (Table 3). However, there were

Table 1

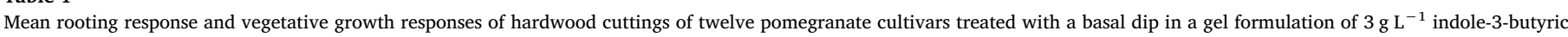
acid and grown in a greenhouse environment for approximately six months (Experiment 1).

\begin{tabular}{|c|c|c|c|c|c|c|c|}
\hline Cultivar & Rooting (\%) & Plant height $(\mathrm{cm})^{\mathrm{a}}$ & Apical shoot growth $(\mathrm{cm})^{\mathrm{a}}$ & Primary shoots (no.) ${ }^{\mathrm{a}}$ & Total shoot length $(\mathrm{cm})^{\mathrm{a}}$ & Branches (no.) ${ }^{a}$ & Relative chlorophyll (SPAD) ${ }^{a}$ \\
\hline Ambrosia & $62.5 \mathrm{ab}^{\mathrm{b}}$ & $20.1 \mathrm{abc}$ & $21.5 \mathrm{ab}$ & $2.2 \mathrm{ab}$ & 32.0abcde & $3.0 \mathrm{abc}$ & $31.2 \mathrm{~b}$ \\
\hline Desertnyi & $96.9 \mathrm{a}$ & $20.1 b c$ & $22.0 \mathrm{ab}$ & $2.0 \mathrm{ab}$ & 32.0 bcde & $2.1 \mathrm{~cd}$ & $30.7 \mathrm{~b}$ \\
\hline Eversweet & $90.6 \mathrm{a}$ & $20.0 \mathrm{c}$ & $22.8 \mathrm{ab}$ & $2.3 \mathrm{ab}$ & 33.7abcd & $2.5 \mathrm{bcd}$ & $32.2 \mathrm{~b}$ \\
\hline Golden Globe & $93.8 \mathrm{a}$ & $27.3 \mathrm{a}$ & $27.0 \mathrm{a}$ & $1.8 \mathrm{~b}$ & 32.4bcde & $1.8 \mathrm{~d}$ & $34.1 \mathrm{ab}$ \\
\hline Green Globe & $21.9 \mathrm{~b}$ & $22.0 \mathrm{abc}$ & $22.0 \mathrm{ab}$ & $2.4 \mathrm{ab}$ & 29.3abcde & 2.7abcd & $35.2 \mathrm{ab}$ \\
\hline Haku Botan & $93.8 \mathrm{a}$ & $19.4 \mathrm{c}$ & $18.2 \mathrm{~b}$ & $2.2 \mathrm{ab}$ & $23.8 \mathrm{e}$ & $2.4 \mathrm{bcd}$ & $37.6 \mathrm{a}$ \\
\hline Ki Zakuro & $100 \mathrm{a}$ & $20.7 \mathrm{bc}$ & $19.7 \mathrm{~b}$ & $1.9 \mathrm{ab}$ & 29.0de & $2.1 \mathrm{~cd}$ & $35.2 \mathrm{ab}$ \\
\hline Loffani & $84.4 \mathrm{a}$ & $22.3 \mathrm{abc}$ & $22.6 \mathrm{ab}$ & $1.9 \mathrm{ab}$ & 29.2cde & $2.0 \mathrm{~cd}$ & $37.2 \mathrm{a}$ \\
\hline Nochi Shibori & $100 \mathrm{a}$ & $20.7 b c$ & $21.4 \mathrm{ab}$ & $2.5 \mathrm{a}$ & $30.5 \mathrm{cde}$ & $2.4 \mathrm{bcd}$ & $34.0 \mathrm{ab}$ \\
\hline Parfianka & $100 \mathrm{a}$ & $22.5 a b c$ & $22.2 \mathrm{ab}$ & $2.3 \mathrm{ab}$ & 40.3ab & $3.7 \mathrm{a}$ & $32.2 \mathrm{ab}$ \\
\hline Phoenicia & $84.4 \mathrm{a}$ & $27.2 \mathrm{ab}$ & $26.3 a$ & $2.4 \mathrm{ab}$ & $38.6 a b c$ & 3.03ab & $33.6 a b$ \\
\hline Wonderful & $96.9 \mathrm{a}$ & $24.9 \mathrm{abc}$ & $25.8 \mathrm{a}$ & $2.4 \mathrm{ab}$ & $41.6 \mathrm{a}$ & $2.80 \mathrm{abc}$ & $33.7 \mathrm{ab}$ \\
\hline$p$-value & $<0.001$ & $<0.001$ & $<0.001$ & 0.005 & $<0.001$ & $<0.001$ & $<0.001$ \\
\hline
\end{tabular}

\footnotetext{
${ }^{\text {a }}$ Rooted cuttings only.
}

${ }^{\mathrm{b}}$ Means within a column sharing a letter are not significantly different at $P<0.05$ using the Holm-Tukey method. 
Table 3

Main effects means for two vegetative growth responses for these cuttings that were not treated (control) or treated with a basal dip in a gel formulation of 1.5 or $3 \mathrm{~g} \mathrm{~L}^{-1}$ indole3-butyric acid (IBA), then rooted and grown in a greenhouse for nine months (Experiment 2). Means and groupings are separated within cultivar.

\begin{tabular}{lll}
\hline Main effect & ${\text { Leaf } \operatorname{area}^{2}\left(\mathrm{~cm}^{3}\right)^{\mathrm{a}}}$ & ${\text { Primary } \operatorname{shoots}^{2}(\text { no. })^{\mathrm{a}}}^{\text {Cultivar }}$ \\
Ambrosia & $12.3 \mathrm{~b}$ & \\
Green Globe & $10.7 \mathrm{~b}$ & 1.8 \\
Wonderful & $15.9 \mathrm{a}$ & 1.5 \\
IBA & & 2.5 \\
Control & 12.4 & \\
$1.5 \mathrm{~g} \mathrm{~L} \mathrm{~L}^{-1}$ & 13.9 & 1.8 \\
$3 \mathrm{~g} \mathrm{~L}^{-1}$ & 12.1 & 1.7 \\
$P$-values & & 2.1 \\
Cultivar & 0.0344 & \\
IBA & 0.9706 & 0.0640 \\
Cultivar*IBA & 0.3935 & 0.5429 \\
\end{tabular}

${ }^{2}$ Means within a column and main effect followed by a common letter are not significantly different at $P<0.05$ using the Holm-Tukey method.

${ }^{\text {a }}$ Rooted cuttings only.

no differences among cultivars or IBA concentrations for number of shoots (Table 3). Plants of 'Wonderful' had greater total shoot length than plants of 'Green Globe', but similar to plants of 'Ambrosia' treated with 0 or $3 \mathrm{~g} \mathrm{~L}^{-1}$ IBA (Table 2).

\section{Discussion}

\subsection{Rooting percentages and dry root mass}

The cultivars with high rooting percentage (> 80\%) were 'Desertnyi,' 'Eversweet,' 'Golden Globe,' 'Haku Botan,' 'Ki Zakuro,' 'Loffani,' 'Nochi Shibori,' 'Parfianka,' 'Phoenicia,' and 'Wonderful.' 'Ambrosia' and 'Green Globe' had lower rooting percentages compared to other cultivars in both experiments. These data are consistent with other studies on rooting of pomegranate cuttings. Karimi et al. (2012) reported significant differences among cultivars for several growth attributes. Highest rooting percentages previously reported were $90 \%$ by Singh et al. (2011), $86.7 \%$ by Polat and Caliskan (2006), and $96.8 \%$ by Owais (2010). Hussain et al. (2012) reported a mean percentage of $75.55 \%$ for hardwood cuttings propagated under different environmental conditions. Overall, research indicated that pomegranate is readily propagated by hardwood cuttings, but there are exceptions, with certain genotypes more difficult to root than others.

'Green Globe' rooted poorly in both experiments, with rooting approximately $25 \%$ that of most other cultivars evaluated. According to Kennedy (2010), 'Mae' is a cultivar in the USDA NCGR collection that also roots poorly using hardwood cuttings, but no published data confirm this report. Further studies are needed to understand why these cultivars consistently root poorly. Dry root mass data are generally in agreement with Owais (2010), who reported a maximum dry root mass of $0.223 \mathrm{~g}$ for hardwood cuttings.

\subsection{Rooting}

In our experiments, a gel formulation of IBA rooting was used. Gel formulations are used less commonly in commercial propagation than liquid or powder formulations, but acceptable rooting was obtained using $3 \mathrm{~g} \mathrm{~L}^{-1}$ IBA for all cultivars except 'Green Globe.' In contrast, Owais (2010) utilized very high concentrations of IBA, up to $12 \mathrm{~g} \mathrm{~L}^{-1}$ IBA and found that cuttings treated with 6 or $9 \mathrm{~g} \mathrm{~L}^{-1}$ IBA had the highest rooting percentages compared to control cuttings, 3 or $12 \mathrm{~g} \mathrm{~L}^{-1}$ IBA. Karimi et al. (2012) reported that rooting percentages of pomegranate were lower for cuttings treated with $1 \mathrm{~g} \mathrm{~L}^{-1}$ IBA when compared to nontreated cuttings. Some of these concentrations of IBA are higher than what is typically used for pomegranate in commercial practice. Our subsequent experiments with higher concentrations of IBA $\left(9 \mathrm{~g} \mathrm{~L}^{-1}\right)$ did not increase rooting percentages of 'Ambrosia' and 'Green Globe,' with 'Ambrosia' and 'Green Globe' having rooting percentages of $38.5 \%$ and $0 \%$, respectively, for dormant hardwood cuttings treated with $9 \mathrm{~g} \mathrm{~L}^{-1}$ IBA. If difficult-to-root cultivars are chosen for nursery propagation, further research on propagation methods will be needed.

The factors causing one pomegranate cultivar to be more successful at rooting than another have not been confirmed. Some research suggests that endogenous auxins explain cultivar differences in propagation. Auxins can regulate gene expression in plant tissues and endogenous auxins are under genetic control (Overvoorde et al., 2010). According to Levin (2006), 'Wonderful' and 'Desertnyi' are related, with 'Wonderful' being one of the parents used to hybridize 'Desertnyi', with the parentage being ('Kazake' $\times$ 'Wonderful') $\times$ 'Wonderful.' Cuttings of both 'Wonderful' and 'Desertnyi' rooted at $96.9 \%$. Whether rooting success is a heritable trait in pomegranate is unknown.

\subsection{Vegetative growth}

There were significant differences in vegetative growth attributes between 'Wonderful' and other cultivars in both experiments. Owais (2010) recommended hardwood cuttings of pomegranate be made $15-20 \mathrm{~cm}$ long and $6-7 \mathrm{~mm}$ in diameter. Our $10-\mathrm{cm}$ cuttings rooted better than the 20-cm hardwood cuttings used by Owais (2010), indicating that cutting the longer cuttings in half not only produces twice as many cuttings, but perhaps better rooting. In both of our experiments, stem diameter had no effect on any attribute measured and many cuttings were less than $6 \mathrm{~mm}$ in diameter. This indicated that more cuttings of smaller diameter may be used, but with the same propagation success.

\section{Conclusion}

'Wonderful,' the industry standard, and nine other fruiting and ornamental cultivars of pomegranate rooted very well using hardwood cuttings treated with a gel formulation of $3 \mathrm{~g} \mathrm{~L}^{-1}$ IBA. Also, differences in certain vegetative growth attributes, such as plant height and branching, could be detected early in the production of some cultivars. This is the first known study to evaluate rooting and vegetative growth of dormant hardwood cuttings of 'Wonderful' and other important cultivars from the USDA NCGR pomegranate collection. Further research is needed to discover methods to enhance the propagation success of the cultivars with poor rooting.

\section{Conflict of interest statement}

The authors declare that there exists no financial, personal interest or belief that could affect the objectivity of this manuscript.

\section{Funding statement}

This research was supported by the University of California Agricultural Experiment Station and by USDA National Institute of Food and Agriculture Hatch projects CA-R-BPS-5032-H and MIS219060.

\section{References}

Day, K.R., Wilkins, E.D., 2009. Commercial pomegranate (Punica granatum L.) production in California. Acta Hortic. 890, 275-285.

Gil, M., Tomás-Barberán, F., Hess-Pierce, B., Holcroft, D., Kader, A., 2000. Antioxidant activity of pomegranate juice and its relationship with phenolic composition and processing. J. Agric. Food Chem. 48 (10), 4581-4589.

Graham, S.A., Hall, J., Sytsma, K., Shi, S.H., 2005. Phylogenetic analysis of the Lythraceae based on four gene regions and morphology. Int. J. Plant Sci. 166 (6), 995. 
Hartmann, H.T., Kester, D.E., Davies, F.E., Geneve, R., 2001. Hartmann and Kester's Plant Propagation: Principles and Practices, seventh ed. Prentice Hall, New Jersey.

Hussain, I., Khattak, A.M., Amin, N.U., Aman, F., Sajid, M., 2012. Response of different pomegranate cuttings types to different environmental conditions. Sarhad J. Agric. 28 (1), 15-18.

Karimi, H.R., Afzalifar, M., Mansouri, M.Z., 2012. The effect of IBA and salicylic acid on rooting and vegetative parameters of pomegranate cuttings. Int. J. Agric. 2 (Special issue), 1085-1091.

Karimi, H.R., 2011. Stenting (Cutting and Grafting)—a technique for propagation pomegranate (Punica granatum L.). J. Fruit Ornam. Plant Res. 19 (2), 73-79.

Kennedy, C.T., 2010. Register of new fruit and nut cultivars list 45: Pomegranate. HortScience 45 (5), 716-756.

Lansky, E.P., Newman, R.A., 2007. Punica granatum (pomegranate) and its potential for prevention and treatment of inflammation and cancer. J. Ethnopharmacol. 109 (2),
$177-206$.

Levin, G.M., 2006. Pomegranate, first ed. Third Millennium Publishing, Tempe.

Overvoorde, P., Fukaki, H., Beeckman, T., 2010. Auxin control of root development. Cold Spring Harb. Perspect. Biol. 2 (6), a001537.

Owais, S.J., 2010. Rooting response of five pomegranate varieties to indole butyric acid concentration and cuttings age. Pak. J. Biol. Sci. 13 (2), 51.

Polat, A.A., Caliskan, O., 2006. Effect of indolebutyric acid (IBA) on rooting of cutting in various pomegranate genotypes. Acta Hortic. 818, 187-192.

Singh, B., Singh, S., Singh, G., 2011. Influence of planting time and IBA on rooting and growth of pomegranate (Punica granatum L.) 'Ganesh' cuttings. Acta Hortic. 890, 183.

Still, D.W., 2006. Pomegranates: A botanical perspective. In: Heber, D., Schulman, R.N., Seeram, N.P. (Eds.), Pomegranates: Ancient Roots to Modern Medicine. CRC Press, Florida, pp. 199-207. 